\title{
EDITORIAL
}

\section{Justifying NATO's Use of Force in Kosovo?}

Keywords: international humanitarian intervention; Kosovo; NATO; use of force; Yugoslavia.

\begin{abstract}
There is no unanimity in the international community about the legality of NATO's use of force in Kosovo in order to avert a humanitarian catastrophe. NATO has acted without Security Council authorization and its arguments for a humanitarian intervention are legally inconsistent. It has set a dangerous precedent. This editorial analyses the legal framework and complexities of the Kosovo crisis and its repercussions on the concept of 'justified use of force'.
\end{abstract}

\section{INTRODUCTION}

At the time of writing of this editorial, an international security force (KFOR) ${ }^{1}$ has been established in Kosovo after NATO carried out air strikes against targets in the Federal Republic of Yugoslavia (FRY) for more than ten weeks. The estimated number of refugees and displaced persons in the region now reaches more than $779,700 .^{2}$ One of NATO's objectives was to halt the violence against the civilian population of Kosovo and avert a humanitarian catastrophe. ${ }^{3}$ Several states, most notably Russia, China and India, have said that NATO's military strikes amounted to a violation of the Charter of the United Nations and international law. ${ }^{4}$ On 29 April 1999, four days after accepting the compulsory jurisdiction of the ICJ, the FRY instituted proceedings before the International Court of Justice against Belgium, Canada France, Germany, Italy, the Netherlands, Portugal, Spain, the United Kingdom, and the United States of America, accusing these states, among others, of violating their obligation not to use force. In all ten cases the Court rejected Yugoslavia's request for the indication of provisional measures because it did not have prima facie jurisdiction, though adding that it was "profoundly concerned with the use of force in Yugoslavia" and that "under the present circumstances such use raises very serious issues of interna-

1. UN Doc. S/RES/1244 (1999), para. 7.

2. As at 7 June 1999, http:/www.unhcr.ch/news/media/kosovo.htm

3. Press Statement by Dr. Javier Solana, Secretary General of NATO, NATO Press Release (1999) 040 (23 March 1999) and Statement Issued at the Extraordinary Ministerial Meeting of the North Atlantic Council, NATO Press Release M-NAC-1(99)51 (12 April 1999).

4. UN Doc. S/PV.3988 (1999) and UN Doc. S/PV.3989 (1999)

12 Leiden Journal of International Law 287-295 (1999)

(c) 1999 Kluwer Law International 
tional law". It further emphasized that "all parties appearing before it must act in conformity with their obligations under the United Nations Charter and other rules of international law, including humanitarian law" ${ }^{6}$ What are the international legal arguments justifying NATO's use of force in Kosovo? ${ }^{7}$

\section{No SECURITY COUNCIL AUTHORIZATION}

Although the Security Council of the United Nations affirmed in 1998 that the situation in Kosovo constituted a threat to peace and security in the region, ${ }^{8}$ NATO was not authorized by the Security Council to use force under Article 53 of the UN Charter. NATO cannot claim to act on the basis of a right to collective self-defence under Article 51 of the UN Charter either, because the air strikes were not in response to an armed attack against a member state of the UN. Moreover, according to Article 1 of the 1949 North Atlantic Treaty, NATO member states must "refrain in their international relations from the threat or use of force in any manner inconsistent with the purposes of the United Nations". Even if NATO justifies its military operations with the argument that the FRY "has repeatedly violated United Nations Security Council resolutions"10 none of the relevant resolutions contain provisions authorizing member states to use force against the FRY. Such an authorization was even explicitly denied by Brazil, China, Costa Rica, and Russia during the debates leading to the adoption of Security Council Resolution $1203(1998) .{ }^{\text {.1 }}$

Nevertheless, on 26 March 1999, the Security Council failed to adopt a draft resolution submitted by Belarus, Russia, and India which qualified NATO's use of force as a "flagrant violation" of Articles 2(4), 24, and 53 of the UN Char-

5. Legality of Use of Force (Yugoslavia v. Belgium), Request for the Indication of Provisional Measures, Order of 2 June 1999, 1999 ICJ Rep. (not yet published), para. 17. The ICJ Orders in the other nine cases are identical mutatis mutandis. See http://www.icj-cij.org/

6. Id., para. 19.

7. See also K. Ambos, Comments: NATO, the UN and the Use of Force: Legal Aspects, 10 EJL (1999) (not yet published); P. Bartl, Kosovo - Historische Ursachen eines Aktuellen Konflikts, 4 Die Friedenswarte 351 (1998); N. Blokker, Over Gesloten Gelederen, Ars Aequi (June 1999) (not yet published); N. Blokker \& D. Raic, Ingrijpen in Kosovo is Onrechtmatig, NRC Handelsblad, 12 October 1998; A. Cassese, Ex Injuria Jus Oritur: Are we Moving towards International Legitimation of Forcible Humanitarian Countermeasures in the World Community?, 10 EJIL (1999) (not yet published); A. Pradetto, NATO - Intervention in Kosovo? Kein Eingreifen ohne UN Mandat, 9 Internationale Politik 41 (1998); B. Simma, NATO, the UN and the Use of Force: Legal Aspects, 10 EJIL (1999) (not yet published) and Ch. Tomuschat, Eine Rein Humanitäre Intervention?, Die Welt, 26 March 1999.

8. UN Doc. S/RES/1199 (1998) and UN Doc. S/RES/1203 (1998).

9. 34 UNTS 243.

10. NATO Press Release M-NAC-1(99)51 (12 April), at 2.

11. UN Doc. S/PV. 3937 (1998). 
ter. ${ }^{12}$ The Netherlands justified NATO's action by arguing that it "follows directly from resolution 1203 , in conjunction with the flagrant non-compliance on the part of the Federal Republic of Yugoslavia". ${ }^{13}$ The United Kingdom considered that "[i]n the current circumstances, military intervention is justified as an exceptional measure to prevent an overwhelming humanitarian catastrophe". ${ }^{14}$ Whereas the United States claimed that the draft resolution by alleging that NATO was acting in violation of the UN Charter "turns the truth on its head". is The supporters of NATO's use of force consider that the enforcement actions are necessary to stop the violence, the grave violations of human rights and of international humanitarian law as well as the ethnic cleansing perpetrated by the regime of President Milošević. The opponents, though not explicitly denying that a threat to the peace existed prior to the NATO bombing, ${ }^{16}$ defend the UN Charter by emphasizing the Security Council's primary responsibility for the maintenance of international peace and security excluding any unilateral military action which undermines the United Nations collective security system. ${ }^{17}$ Even the ICJ in an obiter dictum emphasized that "when such a dispute gives rise to a threat to the peace, breach of the peace or act of aggression, the Security Council has special responsibilities under Chapter VII of the Charter". ${ }^{18}$

At present, KFOR has been established "with all necessary means to fulfil its responsibilities"19 which are, among others, deterring renewed hostilities, enforcing a ceasefire, and preventing the return into Kosovo of Federal and Republic military, police, and paramilitary forces. ${ }^{20}$ Russia considers that the resolution contains "no hint to the possibility of any type of use of force except that set out in the peace agreement". ${ }^{21}$

Though NATO has not acted, and does not pretend to have acted, in conformity with Articles 51 and 53 of the UN Charter, could NATO's use of force still be considered legal? NATO's wish to avert a humanitarian catastrophe is equivalent to saying that NATO wishes to defend the purposes of the United Nations embodied in Article 1 of the UN Charter. Yet, it does not use the Char-

12. UN Doc. S/1999/328 and UN Doc. S/PV.3989 (1999), at 5. The draft resolution was rejected by a vote of 3 in favour (China, Namibia, Russia) to 12 against, with no abstentions.

13. UN Doc. S/PV.3989 (1999), at 4.

14. $I d$, at 7 .

15. Id., at 5 .

16. On 24 October 1998, Russia denied that the situation in Kosovo constituted a continuing threat to peace and security in the region. China has consistently stated that the question of Kosovo was an internal matter of the FRY: UN Doc. S/PV. 3937 (24 October 1998), at 12 and 14. For these reasons China and Russia abstained from voting on Security Council Resolution 1203 (1998).

17. UN Doc. S/PV.3989 (1999), at 5-6.

18. Legality of Use of Force (Yugoslavia $v$. Belgium), supra note 5, para. 50. Same text in the other nine cases. One notices that the Court carefully uses the term "special" responsibilities, not "primary" responsibilities as laid down in Art. 24(1) UN Charter.

19. UN Doc. S/RES/1244 (1999), para. 7.

20. Id., para. 9 .

21. UN Doc. S/PV. 4011 (1999), at 12. 
ter mechanism to achieve these goals. The expected vetoes of China and Russia would have prevented Security Council authorization of NATO air strikes under Article 53 of the UN Charter. However, the NATO member states did not so far try to get an alternative authorization by the General Assembly under the Uniting for Peace Resolution either. ${ }^{22}$ Therefore, NATO's violation of Articles 51 and 53 of the UN Charter can only be justified by invoking international legal norms superior to these Charter provisions, namely ius cogens. By definition no provision of the UN Charter can derogate from ius cogens. ${ }^{23}$ Indeed, it can be argued that one of the purposes of the UN Charter is to protect rules of ius cogens such as fundamental human rights, the right of self-determination and the prohibition of aggression. Does NATO have a ius cogens right to use force to protect these peremptory norms of general international law?

\section{INTERNATIONAL HUMANITARIAN INTERVENTION}

The right of a state to use force against another state to stop the latter from continuing gross violations of fundamental human rights has been defended by several legal scholars. ${ }^{24}$ However, there are widely divergent definitions of this concept of international humanitarian intervention and there remain doubts as to the existence of an opinio iuris and sufficient state practice. ${ }^{25}$ NATO justifies its use of force as a response to "the unrestrained assault" by Yugoslav military forces on Kosovo civilians and the "appalling violations of human rights". ${ }^{26}$ The Security Council of the United Nations has expressed its deep concern about violations of human rights and of international humanitarian law against the Albanian

22. UN Doc. S/RES/377 A(V) of 3 November 1950. See also on unauthorised use of force J. Lobel \& M. Ratner, Bypassing the Security Council: Ambiguous Authorizations to Use Force, Cease-fires and the Iraqi Inspection Regime, 93 AJIL 124 (1999).

23. Obligations under the UN Charter prevail over obligations under any other intemational agreement according to Art. $103 \mathrm{UN}$ Charter, but not over ius cogens which is an international legal norm developed well after the drafting of the UN Charter. See Art. 53 Vienna Convention on the Law of Treaties of 23 March 1969, reproduced in 8 ILM 679 (1969).

24. D. Kritsiotis, Reappraising Policy Objections to Humanitarian Intervention, 19 Michigan Joumal of Intemational Law 1005 (1998); O. Ramsbothan, Humanitarian Intervention 1990 - 5: A need to Reconceptualize, Review of International Studies 445 (1997); O. Ramsbothan \& T. Woodhouse, $\mathrm{Hu}$ manitarian Intervention in Contemporary Conflict: A Reconceptualization (1996); W.M. Reisman, Hollow Victory: Humanitarian Intervention and Protection of Minorities, Proceedings of the ASIL Annual Meeting 431 (1997); O. Schachter, The Legality of Pro-democratic Invasion, 78 AJIL 645 (1984); F.R. Tesón, Humanitarian Intervention: An Inquiry Into Law and Morality (1997); and R. Vincent, Nonintervention and International Order (1974).

25. In the case of Military and Paramilitary Activities in and Against Nicaragua (Nicaragua $v$. United States), Merits, Judgment, 1986 ICJ Rep. 14, at 134-135, the ICJ held that "the protection of human rights, a strictly humanitarian objective, cannot be compatible with the mining of ports, the destruction of oil installations, or again with the training, arming, and equipping of the contras."

26. NATO Press Release M-NAC-I (99)51 (12 April 1999), para. 2. 
minority in Kosovo. ${ }^{27}$ It was also gravely concerned at "the excessive and indiscriminate use of force by Serbian security forces [...] and the displacement of over 230,000 persons from their homes", before NATO bombing started ${ }^{28}$ On 24 March 1999, Milošević, three other Yugoslav high government officials, and the chief of general staff of the VJ were indicted by the Prosecutor of the ICTY for crimes against humanity and violations of the laws or customs of war. Several of the counts relate to crimes committed after NATO bombing started. ${ }^{29}$

The Security Council and NATO demand that the FRY and all Kosovar armed elements immediately cease hostilities. ${ }^{30}$ If NATO considers that the atrocities committed by the FRY are serious enough to justify its air strikes, how could it deny the Kosovar victims the use of force against the FRY in 1998? NATO contradicts its own arguments by stating that "[a]ll parties must end violence and pursue their goals by peaceful means only". ${ }^{31}$ Are the goals of the Albanian minority in Kosovo not the same as NATO's? If they are, NATO's use of force could be considered illegal either because the violations of fundamental human rights are not grave enough, or because there is no right of self-defence against the perpetrators of the violations of ius cogens. Even the Interim Agreement for Peace and Self-Government in Kosovo (Rambouillet Agreement), accepted by the Kosovo Albanian leadership, provides that "alleged violations of the cease-fire [...] shall not be used to justify use of force in response". ${ }^{32}$ A right of self-defence is denied to all parties in the Kosovo conflict.

Moreover, the Security Council has called upon the Kosovar Albanian leadership "to condemn all terrorist action". ${ }^{33}$ The violence used by Kosovar armed elements in response to the abolition of Kosovo's autonomous status in 1990 is qualified as terrorism. ${ }^{34}$ Yet, the NATO bombing (inherently more extensive than the terrorist actions) in order to force the government of the FRY to accept the Rambouillet Agreement, which guarantees an enhanced autonomous status for Kosovo, is considered justified by NATO. The Security Council has condemned "all external support for terrorist activity in Kosovo, including finance,

27. UN Doc. S/RES/1 199 (1998). See also Human Rights Watch, Open Wound: Human Rights Abuses in Kosovo (1993).

28. UN Doc. S/RES/1199 (1998), preamble.

29. Prosecutor v. Milošević \& Others, Indictment, Case No. IT-99-37, 24 May 1999, at 18-31. See http:/www.un.org/icty/indictment/english/24-05-99milo.htm. They are accused of deportations, murders, and persecutions of Kosovo Albanian civilians beginning in January 1999.

30. UN Doc. S/RES/1119 (1998), para. 1 and NATO Press Release (99)II (28 January 1999), para. 2.

31. NATO Press Release (99)11 (28 January 1999), para. 2 (emphasis added).

32. Art. II(1) Rambouillet Agreement; http://www.state.gov/www/regions/eur/ksvo rambouillet text html.

33. UN Doc. S/RES/1160 (1998), para. 2; UN Doc S/RES/1199 (1998), para. 6; and UN Doc. S/RES/1203 (1998), para. 10. On the absence of a definition of terrorism see Y. Dinstein, The Right of Self-Defence Against Armed Attacks, in M.D. Sandbu \& P. Nordbeck (Eds.), International Terrorism: Report from a Seminar Arranged by the European Law Students' Association in Lund 57 (1989)

34. Id., preambles. 
arms and training". ${ }^{35}$ If the Kosovo Liberation Army (KLA) had used the same military force against the government of the FRY as NATO is using now, with e.g. the external support of NATO member states, would it not have fallen under the Security Council condemnation of external support for terrorist activity? ${ }^{36}$ The difference can probably be explained by the fact that the international community has up to now prohibited military interference by third states to help secessionists and entitled states to use police enforcement measures to defend their territorial integrity and to prevent secessions. ${ }^{37}$ Now, NATO has set a precedent by defending the legality of the use of force for the purpose of attaining autonomy if a people has been forcibly deprived of that autonomy. One may conclude that NATO is defending the ius cogens right to internal self-determination of the people of Kosovo, but, oddly enough, without leaving them much choice. Belgrade and the Kosovo Albanian leadership were asked to agree to the Rambouillet Agreement under the threat of NATO's use of force. ${ }^{38}$ Such an agreement cannot be valid if its conclusion has been procured by the threat or use of force in violation of the UN Charter. ${ }^{39}$

NATO and the European Union have often stated that they had "a moral duty", not explicitly a legal one, to end the violence and the humanitarian catastrophe in Kosovo ${ }^{40}$ According to the legal concept of international humanitarian intervention, the force used must be proportional to the violations of the rights defended and cease as soon as these violations end. The legality of the intervention by NATO then also depends on the necessity of the military action to obtain the required results. In order to test the proportionality of the force used, how much legal weight should be given to the fact that NATO could have known that its air strikes would increase the deportations and the refugee crisis? How many civilian casualties and erroneous attacks, such as on the Chinese embassy in Belgrade, will still be considered proportional to the results obtained? There are some inconsistencies in the legal justifications advanced by NATO which may set a legal precedent outside the UN security framework.

35. Id.

36. The main purpose of the KLA is "the achievement of freedom" and "the establishment of a democratic system". Though, unlike NATO, it seeks independence for Kosovo, it claims to defend the people of Kosovo against the violence used by the Yugoslav army in Kosovo: KLA Political Statement No. 26 (5 February 1999). See http://www.kosovapress.com/english/index .htm.

37. J. Duursma, Fragmentation and the International Relations of Micro-States: Self-Determination and Statehood 426-428 (1996).

38. NATO Press Release (99)11 (28 January 1999), paras. 3 and 6.

39. Cf. Art. 521969 Vienna Convention of the Law of Treaties, supra note 23.

40. NATO Press Release (1999)041 (24 March 1999) and European Council Statement (25 March 1999), in 7433 EUROPE (26 March 1999), at 5. 


\section{LEGALITY OF USE OF FORCE CASES BEFORE THE ICJ}

In all ten cases considered separately by the ICJ, the FRY claimed that the states by taking part in the bombing of its territory had violated their obligation not to use force and that by taking part in the training, arming, financing, equipping and supplying of the KLA had violated their obligation of non-intervention. ${ }^{41}$ In addition, claims were made concerning breaches of international humanitarian law, environmental law, basic human rights, freedom of navigation on international rivers, and allegations of genocide. The cases presented complex legal questions concerning the prima facie jurisdiction of the Court. Three bases for jurisdiction were examined.

First, Article 36(2) of the Statute of the ICJ. Yugoslavia had accepted the compulsory jurisdiction of the Court using the standard formula: "in all disputes arising or which may arise after the signature of the present Declaration, with regard to the situations or facts subsequent to this signature", 42 i.e. after 25 April 1999. The majority of the judges concluded that in essence the applications were directed against the bombing of the territory of the FRY and that a legal dispute on this arose well before 25 April 1999. Although it admitted that the dispute had persisted since that date, Yugoslavia had not established that new disputes, distinct from the initial one had arisen since 25 April $1999 .{ }^{43}$ This is a surprisingly narrow interpretation of the "arisen" legal dispute. The Court reduces the legal dispute to the contested bombing and ignores the claims concerning violations of international humanitarian law, environmental law, basic human rights and freedom of navigation on international rivers which are a consequence of the bombing and therefore may have arisen after 25 April 1999, but which are not an inherent and inseparable part of it. If the use of force were legal for the purposes of averting a humanitarian catastrophe, substantial civilian casualties could nevertheless have been considered a violation of international humanitarm ian law and therefore a new legal dispute. It is a question of the legality of the bombing strategy used apart from the legality of the bombing itself. ${ }^{44}$ Both Spain and the UK escaped jurisdiction on the basis of the exceptions they had made in their declarations under Article 36(2) of the Statute of the ICJ. ${ }^{45}$

Second, Article IX of the Convention on the Prevention and Punishment of the Crime of Genocide. ${ }^{46}$ In eight cases, the Court did not consider that the acts

41. Legality of Use of Force (Yugoslavia v. Belgium), supra note 5, para. 4.

42. Id., para, 23 (emphasis added).

43. Id., paras. $28-29$.

44. See also id., dissenting opinions of Judges Weeramantry and Vereshchetin

45. They did not accept jurisdiction for disputes in regard of which the other party had accepted the Court's computsory jurisdiction less than 12 months prior to the filing of the application. See Multilateral Treaties Deposited With the Secretary-General, status as at 31 December 1997, at 25 and 27.

46. 1948 Convention on the Prevention and Punishment of the Crime of Genocide, 78 UNTS 277 (1951) (Genocide Convention). 
imputed by Yugoslavia to the respondents came within the provisions of the Genocide Convention, mainly due to the absence of an element of intent to commit genocide on a group as such. ${ }^{47}$ In the cases of Spain and the USA, no jurisdiction was found as the two states had made a reservation to Article IX of the Genocide Convention to which Yugoslavia had not objected and which was not explicitly prohibited by the Genocide Convention. ${ }^{48}$ The Court did not examine whether the reservations were compatible with the object and purpose of the Genocide Convention.

Third, Article 4 of the Convention of Conciliation, Judicial Settlement and Arbitration between Belgium and the Kingdom of Yugoslavia of 25 March 1930 and Article 4 of the Treaty of Judicial Settlement, Arbitration and Conciliation between the Netherlands and the Kingdom of Yugoslavia of 11 March 1931. Both treaties were presented to the Court in the second round of oral argument. Too late, according to the ICJ, to be considered without the consent of the respondents as it "seriously jeopardizes the principle of procedural fairness and the sound administration of justice". ${ }^{49}$ As is customary, Yugoslavia had reserved the right to amend and supplement its application. Judge Vereshchetin considered the Court's finding contrary to Article 38 of the Rules of Court and its jurisprudence.$^{50}$ It seems odd indeed that considering the seriousness of the alleged violations of the prohibition of the use of force and the number of potential victims, the Court did not extend the hearings so as to allow more time for the respondent states to prepare their defence.

The ICJ decided to remove the cases against Spain and the USA from its list. In the other eight cases it reserved the subsequent procedure for further decision.

\section{CONCLUSIONS}

Considering the above analysis, NATO has taken considerable risks by justifying its use of force in Kosovo outside the UN framework. It may open the door to more violence in the future either by victims of human rights abuses (whether serious or not) or by people seeking a greater degree of self-government. States may use the humanitarian intervention argument now more readily to circumvent the Security Council and defend their political or economic interests by

47. Legality of Use of Force (Yugoslavia v. Belgium), supra note 5, para. 40.

48. The USA reservation made jurisdiction of the ICJ subject to the specific consent of the USA in each case. Spain has made a general reservation to Art. IX. Three states parties (Greece, Mexico and the Netherlands) have objected to the USA reservation as they considered it incompatible with the object and purpose of the Genocide Convention. See Multilateral Treaties Deposited With the SecretaryGeneral, status as at 31 December 1997, at 88-90.

49. Legality of Use of Force (Yugoslavia $v$. Belgium), supra note 5, para. 44; and Legality of Use of Force (Yugoslavia $v$. The Netherlands), Request for the Indication of Provisional Measures, Order of 2 June 1999 , para. 44

50. Id., dissenting opinion in both cases. 
using force against other states. No one will deny the need to end all atrocities that have been committed in the FRY. Yet, unilateral military actions without Security Council authorization need a more solid and consistent legal basis than NATO provides now. It seems that within NATO, military advisers have had more influence than legal advisers. This may lead to a reversal of the disarmament process and a slow-down of the reform of the Security Council. ${ }^{51}$

Moreover, the forced establishment of an international interim administration in Kosovo with the deployment of international military forces on the ground will only be valid with the authorization of the FRY or the Security Council acting under Articles 41 and 42 of the UN Charter. ${ }^{52}$

One overall conclusion imposes itself: instead of using force to avert a humanitarian catastrophe and re-establish self-government in Kosovo, the international community might consider establishing a judicial organ before which minorities and peoples can credibly complain about the violations of their right to autonomy and of their minority rights. Legal prevention is more effective than a military response when the atrocities have already been committed.

Jorri Duursma

51. See UN Press Release DC/2637 (13 April 1999)

52. See also Summary of Deliberations of the European Council, 7446 EUROPE (16 April 1999). 